\title{
Erratum to: Access to Higher Public Education and Location Choices of Undocumented Migrants: An Exploratory Analysis
}

\author{
Richard J. Cebula ${ }^{1}$ • Usha Nair-Reichert ${ }^{2}$
}

Published online: 9 June 2015

(C) International Atlantic Economic Society 2015

\section{Erratum to: Int Adv Econ Res (2015) 21:189-199 DOI 10.1007/s11294-015-9522-3}

\begin{abstract}
Many states have experienced a large influx of undocumented migrants in recent years. This phenomenon has created new demands on higher educational systems at the state level. Some states have passed legislation to restrict the access of undocumented migrants to higher public education whereas others provide access in various forms including in-state tuition. Our research examines a related issue that has not been researched much, namely, the impact of educational access on the location decisions of undocumented migrants in the U.S. Undocumented migrants appear to locate in states with high average median real per capita incomes. There is also evidence of clustering of undocumented migrants in states with large migrant networks. The effect of educational access on the percentage of undocumented workers in a state is mixed and small in most specifications, a finding perhaps indicative of a trade-off between competing priorities in the choice of location.
\end{abstract}

Keywords Undocumented migrants or immigrants · Illegal migration · Migrant networks · Network-based migration $\cdot$ Migrant clustering, Migrant location decisions

JEL Classification J61 $\cdot \mathrm{J} 62 \cdot \mathrm{J} 69$

Correction: There was an error in the order of authorship on page 189 in the May 2015 (Volume 21, No.2) issue of International Advances in Economic Research. This Erratum displays the corrected version. Sincere apologies to the authors.

The online version of the original article can be found at doi 10.1007/s11294-015-9522-3.

Usha Nair-Reichert

usha.nair@gatech.edu

Richard J. Cebula

rcebula@ju.edu

1 Jacksonville University, Jacksonville, FL, USA

2 School of Economics, Georgia Institute of Technology, Atlanta, GA 30332-0615, USA 


\section{Introduction}

Many states have experienced a large influx of undocumented migrants in recent years. This phenomenon has created new demands on the educational systems at the state level, resulting in several state-level educational policy reforms, some favoring and others limiting access of undocumented migrants to higher public education. Our research examines the impact of differences in state-level policies regarding access to higher or post-secondary education on the location choices of undocumented migrants.

The Pew Hispanic Center uses the term "unauthorized migrant" to refer to"a person who resides in the U.S. but who is not a U.S. citizen, has not been admitted for permanent residence, and is not in a set of specific authorized temporary statuses permitting longer-term residence and work." Roughly 30\% of the foreign-born population in the US in 2005 was comprised of undocumented migrants (Passel 2006). There was also considerable variation in the percentage of undocumented migrants across states, with California (24\%), Texas (14\%), Florida (9\%), New York (7 \%), Arizona (5\%), Illinois (4\%), New Jersey (4\%), and North Carolina (3\%) having the highest concentrations of undocumented migrants during 2002-2004 (Passel 2005). ${ }^{1}$

Different states have responded to the new and additional demands on their public educational systems in different ways. Some states have passed legislation to restrict the access of undocumented migrants to higher education whereas others provide access in various forms including in-state tuition. The National Conference of State Legislatures (2014) indicates that eighteen states currently allow in-state tuition for undocumented students. California, Colorado, Connecticut, Florida, Illinois, Kansas, Maryland, Minnesota, Nebraska, New Mexico, New Jersey, New York, Oregon, Texas, Utah, and Washington have passed state-level statutes covering in-state tuition rates to undocumented students, while Oklahoma and Rhode Island do so through Board of Regents decisions. Arizona, Georgia, and Indiana barred undocumented students from receiving in-state tuition rates in 2006, 2008 and 2011, respectively. South Carolina and Alabama barred undocumented students from enrolling in public postsecondary institutions in 2008 and 2011, respectively. These policy changes are a part of the contentious and contested debates across the nation regarding the burdens and benefits of illegal immigration and the need for comprehensive immigration reform.

There is very little direct research on the impact of educational access on the location decisions of undocumented migrants in the US, despite the contentious nature of the matter. This study examines four broad sets of factors at the state level that arguably influence the number of undocumented migrants residing in a state as a percentage of the total state population, namely, economic opportunities, educational access policies, size of migrant network, and the quality of life. Previous research has identified greater economic opportunities as an important determinant of the percentage of undocumented migrants at the state level (Cebula et al. 2013; Cebula et al. 2014; Nair-Reichert 2014). Our analysis of educational opportunities can be thought of as expanding the role of economic

\footnotetext{
1 "The appearance of Arizona and North Carolina on this list highlights another recent trend. In the past, the foreign-born population, both legal and unauthorized, was highly concentrated. But, since the mid-1990s, the most rapid growth in the immigrant population in general and the unauthorized population in particular has taken place in new settlement areas where the foreign born had previously been a relatively small presence (Passel 2005)."
} 
opportunities by introducing an inter-generational component, namely, the education and future income potential of part of the next generation in the U.S., the children of illegal migrants.

Undocumented migrants are more likely to locate in states that offer greater economic opportunities, which is consistent with income-maximizing behavior. Economic opportunities at the state level have been variously proxied in previous research by median family income, welfare benefits, lower cost of living, state tax rates, and rates of unionization. The welfare magnet hypothesis suggests that foreign-born welfare recipients whose objective is to maximize their incomes may be clustered in the states that offer the highest benefits (Borjas 1999). ${ }^{2}$ The current research also relates to the literature on welfare magnets because access to in-state tuition can be considered as another attractive form of benefit for undocumented migrants and their children. Undocumented migrants would likely prefer states with no income tax, ceteris paribus, as residing in such states would lower both their tax burden and elevate the probability of detection by the government and law enforcement authorities (Tullock 1971; Conway and Houtenvile 2003; Gale and Heath 2000; Cebula and Alexander 2006).

Network-based migration may also explain the location choice of an undocumented migrant. The economic and non-economic costs of immigration are lower in host countries with existing migrant networks and therefore influence the choice of the destination country (Carrington et al. 1996; Bauer et al. 2002; Cebula et al. 2013). This same argument is applicable to the choice of the destination state once the undocumented migrant is in the U.S. In the Council of Economic Advisors (2005, p. 110), it is observed that "Once workers are here, additional undocumented immigration may take place as family members and friends join the workers." The literature identifies climatic conditions as a quality of life variable that impacts location decisions of migrants since they are more likely, ceteris paribus, to gravitate towards warmer and more comfortable climates where they are likely to find more work in occupations such as construction, landscaping, and farming (Saltz 1998; Cebula and Alexander 2006, Cebula, et al. 2013). Passel (2006) estimated that undocumented migrants constituted approximately $24 \%$ of all workers employed in farming occupations, $17 \%$ in cleaning, $14 \%$ in construction, and $12 \%$ in food preparation industries.

Our results indicate that the effect of educational access on the percentage of undocumented workers in a state is mixed and very small in most specifications, indicating perhaps a trade-off between competing priorities in their choice of location. Interestingly, the interaction terms between the educational access variables and the networks variable is negative, suggesting that even among states that have a favorable education policy, undocumented migrants prefer states where there is likely to be a smaller number of undocumented migrants competing for admission.

\section{Related Literature}

While there is relatively little direct literature on the impact of educational access on the location choices of undocumented workers, we can gather important insights from papers examining the impact of such educational policy changes on the educational

\footnotetext{
2 The Council of Economic Advisors (2005, p. 110) notes "To obtain work, some undocumented immigrants resort to using false documents, such as fake Social Security cards or green cards."
} 
outcomes of undocumented migrants. In general, the impact of educational policy changes on educational outcomes of undocumented migrants is mixed and somewhat limited. Kaushal (2008) analyzed data for Mexican noncitizen young adults in 10 states that offered in-state tuition benefits to unauthorized migrants in an attempt to approximate the results for the unauthorized migrant population. He concluded that tuition benefit laws have had positive but limited effects on college enrollment by Mexican noncitizen students. The study considers only a sample of the population that came to the US before 2001 and had been in the country for at least three years, and it did not include non- Mexican migrants. Stella M. Flores (2010) concluded that students who are likely to be undocumented are also more likely to attend college in states with in-state tuition benefits. Flores and Horn (2009) analyzed data on in-state tuition recipients who were likely to be undocumented at a selective public institution in Texas and concluded that they were as likely to graduate as a comparable group of Latino students born in the US.

Chin and Juhn (2010) exploit state and time variation in the passage of the educational laws benefitting undocumented migrants to examine the effects of these laws on the probability of attending college for 18- to 24-year-olds who have a high school degree. They use individual-level data for 2001-2005 from the American Community Surveys and the 2000 U.S. Census. Chin and Juhn (2010, p. 1) find "some evidence suggestive of a positive effect of the laws on the college attendance of older Mexican men, although estimated effects of the laws in general are not significantly different from zero.” Zota (2008, p. 51) summarizes the limited impact of these educational policies on enrollments evidenced in previous research. In particular, she observes that " ....in the four states that enacted tuition benefit laws prior to 2003, California (2001), New York (2002), Texas (2001), and Utah (2002), college enrollment among Mexican noncitizen youth increased by only 1.2 percent from 1999 to 2002. From 2002 to 2005, enrollment increased by 3.5 percent. Although the increase in college enrollment among Mexican noncitizen youth is significant for that population, it is not dramatic enough to narrow the attainment gap between noncitizens and natives [. . . So, although the impact of the tuition benefit laws may be significant for portions of the population and for individuals, college enrollment as a whole remains largely unaffected." The difference between in-state and out-of-state tuition is substantial.

Kaushal (2008, p. 771) indicates that "In the 2004-2005 academic year, community colleges in states that provided in-state tuition to the undocumented had average tuition and fees of $\$ 1,938$ for residents and $\$ 5,783$ for nonresidents; the average undergraduate tuition and fees in public colleges and universities in these states was $\$ 3,935$ for residents and \$10,860 for nonresidents" (Washington Higher Education Coordination Board, 2005). Dougharty et al. (2010) address the large negative impact of the sizable difference in out-of-state and in-state tuition and fees on undocumented migrants because they tend to have low family incomes. Compounding this problem is the fact that they are not eligible for federal financial aid (Biswas 2005; Perry 2004; Szelenyi and Chang 2002) and do not qualify for state student aid except in Texas and New Mexico (Dougherty et al. 2006). Moreover, it is hard for undocumented students to get private funding (Hausman and Goldman 2001). Hence, undocumented workers interested in their own higher education or that of their children have an incentive to move to states with favorable educational access policies.

However, as Chin and Juhn (2010) have suggested, lack of access to financial aid (especially federal financial aid) to pay for the in-state tuition and other college expenses, 
and the employer sanctions under the Immigration Reform and Control Act that limit undocumented migrants' prospects of obtaining higher level jobs even with college degrees may impede these students from participating in higher education, despite access to in-state tuition. Overall, the effective utilization of avenues for higher education in states with favorable in-states tuition policies appears to be somewhat limited. This in turn suggests that favorable educational policies for undocumented migrants may have a limited impact on their location decisions. This is an empirical issue that we explore in the next section.

\section{Analytical Framework}

We adopt a cost-benefit analysis approach wherein the undocumented migrant making a location decision weighs the expected costs and benefits over her lifetime. An undocumented migrant who has decided to migrate to the U.S. from home country $i$ now has the choice of migrating to any of the $j$ states, where $j$ ranges from 1 to 50 . An undocumented migrant from country $i$ will chose to migrate to state $j(=1)$ if and only if her expected net discounted present value from that action, $D P V_{i j}$, is both positive and is the highest net discounted present value she can obtain in comparison to locating in any of the other $j$ states (where $j \neq 1$ ). ${ }^{3}$ This is captured by Eq. (1):

$$
D P V_{i j}>0 ; \text { and } D P V_{i j}=\max \left(D P V_{i j}\right) \text { for } j, \text { where } j=1,2, \ldots, 50
$$

We use the Tiebout-Tullock hypothesis as a framework for this analysis since it models the consumer-voter as evaluating both the government goods and services and the tax burden at the locations of choice in determining whether to migrate to state $j$. Several other papers have followed this approach and considered two broad sets of determinants that impact $D P V_{i j}$, namely, economic conditions and quality of life conditions in those states (Riew 1973; Renas 1983; Vedder et al. 1986; Cebula and Alexander 2006; Nair-Reichert 2014). The present study follows this approach and examines four broad sets of factors at the state level that influence $D P V_{i j}$ and thus the percentage of undocumented migrants in a state, namely economic opportunities, educational access policies, size of migrant network, and the quality of life. Table 1 describes the variables and data sources. Table 2 provides the correlation coefficients for the key variables used in the analysis. Table 3 indicates the list of states that had implemented educational access policies favorable to undocumented workers by 2005 .

The data on the percentage of undocumented migrants as a part of the total population at the state level is from the PEW 2005 Survey. Our dependent variable umrate $_{j}$ is the log of the percentage of undocumented migrants in state $j$ in 2005 . We express the stock of undocumented migrants as a percent of the state's total population to facilitate comparisons of the undocumented migrant location decisions across states. The Pew Hispanic Center (Passel 2005) estimates the total stock of undocumented migrants in the U.S. in 2005 to be 11.1 million.

\footnotetext{
$\overline{{ }^{3} \text { We do not consider factors such }}$ as distance and moving costs in calculating $D P V_{i j}$ as reliable data are largely unavailable in the case of undocumented migrants.
} 
Table 1 Definition of variables and data sources

\begin{tabular}{|c|c|c|c|}
\hline Variable name & $\begin{array}{l}\text { Variable name } \\
\text { definition }\end{array}$ & Description & Source \\
\hline umrate $_{j}$ & $\begin{array}{l}\% \text { undocumented } \\
\text { migrants (in logs) }\end{array}$ & $\begin{array}{l}\text { \% undocumented migrants } \\
\text { in state } j \text { 's population - } \\
2005\end{array}$ & $\begin{array}{l}\text { Passel and Cohn (2011), U.S. } \\
\text { Census Bureau Table } 17 \text { (2007). }\end{array}$ \\
\hline networks $_{j}$ & $\begin{array}{l}\text { Hispanic population } \\
\quad(\operatorname{logs})\end{array}$ & $\begin{array}{l}\text { total Hispanic population in } \\
\text { state } j\end{array}$ & $\begin{array}{l}\text { Population Division, Census } \\
\text { Bureau, Table 4, July 1, } 2004 \\
\text { (SC-EST2004-04) }\end{array}$ \\
\hline rmedinc $_{j}$ & $\begin{array}{l}\text { Median real income } \\
2004(\operatorname{logs})\end{array}$ & $\begin{array}{l}\text { real median family income } \\
\quad \text { in } 2004 \text { in state } j\end{array}$ & $\begin{array}{l}\text { Census Bureau, Table H- } 8 \text {. Median } \\
\text { Household Income by State: } \\
1984 \text { to } 2012\end{array}$ \\
\hline$i n c \_\operatorname{taxs}_{j}$ & $\begin{array}{l}\text { State income tax } \\
\text { dummy }\end{array}$ & $\begin{array}{l}=1 \text { if state has income tax; } \\
0 \text { otherwise }\end{array}$ & $\begin{array}{l}\text { U.S. Census Bureau (2005, } \\
\text { Table 455) }\end{array}$ \\
\hline jan_temp $p_{j}$ & $\begin{array}{l}\text { Average Jan. } \\
\text { temperature }\end{array}$ & $\begin{array}{l}\text { average temperature in } \\
\text { January in state } j\end{array}$ & $\begin{array}{l}\text { U.S. Census Bureau (2005, } \\
\text { Table 378) }\end{array}$ \\
\hline ed_fav_im_dum & $\begin{array}{l}\text { Favorable educational } \\
\text { policy dummy }\end{array}$ & $\begin{array}{l}\text { value }=1 \text { if a state has } \\
\text { access policies such as } \\
\text { in-state tuition for un- } \\
\text { documented migrants; } \\
0 \text { otherwise. }\end{array}$ & $\begin{array}{l}\text { http://www.ncsl.org/research/ } \\
\text { education/undocumented-student- } \\
\text { tuition-state-action.aspx }\end{array}$ \\
\hline ed_eff_yrs & $\begin{array}{l}\text { \# years of favorable } \\
\text { educational policy }\end{array}$ & $\begin{array}{l}\text { total \# of years the policy } \\
\text { has been in effect in the } \\
\text { state }\end{array}$ & $\begin{array}{l}\text { calculated by authors from } \\
\text { ed_fav_im_dum }\end{array}$ \\
\hline ed_fav_networks & $\begin{array}{l}\text { Favorable educational } \\
\text { policy } * \text { networks }\end{array}$ & $\begin{array}{l}\text { Interaction term between } \\
\text { favorable educational } \\
\text { access policy and } \\
\text { networks (logs) }\end{array}$ & \\
\hline ed_eff_networks & $\begin{array}{l}\text { \# years favorable } \\
\text { educational policy } \\
\text { *networks }\end{array}$ & $\begin{array}{l}\text { Interaction term between \# } \\
\text { years favorable } \\
\text { educational access policy } \\
\text { and networks (logs) }\end{array}$ & \\
\hline
\end{tabular}

Table 2 Correlation matrix

\begin{tabular}{|c|c|c|c|c|c|c|c|}
\hline Variable name & $\begin{array}{l}\text { Percent } \\
\text { undocumented } \\
\text { workers }\end{array}$ & $\begin{array}{l}\text { Networks } \\
(\operatorname{logs})\end{array}$ & $\begin{array}{l}\text { Average } \\
\text { Jan. } \\
\text { temp. }\end{array}$ & $\begin{array}{l}\text { Median } \\
\text { income } \\
(\operatorname{logs} 2004)\end{array}$ & $\begin{array}{l}\text { State } \\
\text { income } \\
\text { tax } \\
\text { dummy }\end{array}$ & $\begin{array}{l}\text { Favorable } \\
\text { educational } \\
\text { policy } \\
\text { dummy }\end{array}$ & $\begin{array}{l}\text { Number of years } \\
\text { favorable } \\
\text { educational } \\
\text { policy }\end{array}$ \\
\hline umrate $_{j}$ & 1 & & & & & & \\
\hline networks $_{j}$ & $0.5755^{*}$ & 1 & & & & & \\
\hline jan_temp $p_{j}$ & $0.4111 *$ & $0.3466^{*}$ & 1 & & & & \\
\hline rmedinc $_{j}$ & $0.2891 *$ & 0.072 & -0.1287 & 1 & & & \\
\hline inc_taxs $_{j}$ & $-0.2674 *$ & -0.1799 & -0.0549 & -0.1485 & 1 & & \\
\hline ed_fav_im_dum & $0.28 *$ & $0.4962 *$ & 0.0821 & 0.0257 & -0.111 & 1 & \\
\hline ed_eff_yrs \# & 0.3689 & $0.6882 *$ & 0.1318 & 0.0735 & -0.1581 & 0.9242 & 1 \\
\hline
\end{tabular}

* significance at the 5\% level or higher 
Table 3 States with educational access policies favorable to undocumented migrants by 2005

\begin{tabular}{llll}
\hline State & $\begin{array}{l}\text { Year policy } \\
\text { passed }\end{array}$ & $\begin{array}{l}\text { ed_fav_im_dum=1 for } \\
\text { these states; }=0 \text { otherwise }\end{array}$ & ed_effyrs \\
\hline California & 2001 & 1 & 5 \\
llinois & 2003 & 1 & 3 \\
Kansas & 2004 & 1 & 2 \\
New Mexico & 2005 & 1 & 4 \\
New York & 2002 & 1 & 3 \\
Oklahoma & 2003 & 1 & 5 \\
Texas & 2001 & 1 & 4 \\
Utah & 2002 & 1 & 3 \\
Washington & 2003 & 1 & 4 \\
\hline
\end{tabular}

We consider two measures of educational access for undocumented migrants: a variable ed_fav_im_dum (favorable educational policy dummy) that equals 1 if a state has a favorable educational policy towards undocumented migrants and equals 0 otherwise. Another variable, ed_eff_yrs (number of years since favorable educational policy was enacted), captures the number of years since the favorable educational policy was implemented by the state.

Undocumented migrants appear to locate in states with high average median real per capita incomes. There is also evidence of clustering of undocumented migrants in states with large migrant networks. The economic opportunities in state $j$ are proxied by the log of real median income in 2004 rmedinc $_{i j}$ and the state income tax rate dummy inc_tax ${ }_{i j}$ that equals 0 when the state has no income tax. ${ }^{4}$ We use lagged values of these explanatory variables to address potential endogeneity issues and also because migration decisions in year $t$ are often based on economic conditions prevailing in the previous period. The proxy for the size of the migrant network is the log of the total documented Hispanic population at the state level network $k_{i j}$ as $56 \%$ of the unauthorized migrants in the U.S. in 2005 were from Mexico (Passsel 2006). The mean January temperature at the state level for the period 1971- 2000 is a proxy for climatic conditions and quality of life in a state.

The basic model is estimated using Equation (2) below:

$$
\begin{aligned}
\text { umrate }_{j}= & \alpha_{1}+\alpha_{2} \text { network }_{j}+\alpha_{3} \text { rmedinc }_{j}+\alpha_{4} \text { jan_temp }_{j}+\alpha_{5} \text { ed_fav_im_dum } \\
& +\alpha_{6} \text { ed_fav_networks }{ }_{j}+\alpha_{7} \text { inc_taxs }_{j}+\varepsilon
\end{aligned}
$$

We also report other specifications with the number of years of favorable educational policy in each state (ed_eff_yrs) and its interaction with our network variable (ed_eff_networks). We expect the coefficients for jan_temp $p_{j}$ and inc_taxs $s_{j}$ to be negative and significant, and those for all other independent variables to be positive and significant coefficients with the exception of the educational access variables where the

\footnotetext{
${ }^{4}$ The coefficients of the logged independent variables are interpreted as elasticities.
} 
Table 4 Education policy and location choices of undocumented migrants

\begin{tabular}{|c|c|c|c|c|}
\hline 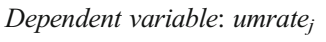 & Model 1 & Model 2 & Model 3 & Model 4 \\
\hline \multirow[t]{2}{*}{ networks $_{j}$} & $0.35 * *$ & $0.36^{* *}$ & $0.38 * *$ & $0.38^{* *}$ \\
\hline & $(6.05)$ & $(5.92)$ & $(5.7)$ & $(5.91)$ \\
\hline \multirow{2}{*}{ jan_temp $p_{j}$} & 0.01 & 0.01 & 0.01 & 0.01 \\
\hline & (1.18) & $(1.16)$ & $(1.14)$ & $(1.21)$ \\
\hline \multirow[t]{2}{*}{ rmedinc $_{j}$} & $1.91 * *$ & $1.90 * *$ & $1.85^{* *}$ & $1.87^{* *}$ \\
\hline & $(3.98)$ & $(4.01)$ & (3.99) & $(4.02)$ \\
\hline \multirow[t]{2}{*}{ inc_taxs } & -0.23 & -0.25 & -0.27 & -0.27 \\
\hline & $(-1.44)$ & $(-1.53)$ & $(-1.64)$ & $(-1.63)$ \\
\hline \multirow[t]{2}{*}{ ed_fav_im_dum } & -0.11 & & $2.36^{* *}$ & \\
\hline & $(-0.67)$ & & $(2.73)$ & \\
\hline \multirow[t]{2}{*}{ ed_eff_yrs number of } & & -0.06 & & $0.47^{*}$ \\
\hline & & $(-1.06)$ & & $(2.25)$ \\
\hline \multirow[t]{2}{*}{ ed_fav_networks } & & & $-0.18^{*}$ & \\
\hline & & & $(-2.65)$ & \\
\hline \multirow[t]{2}{*}{ ed_eff_networks } & & & & $-0.04 *$ \\
\hline & & & & -2.44 \\
\hline \multirow[t]{2}{*}{ Constant } & $-23.97 * *$ & $-24.08^{* *}$ & $-23.77 * *$ & $-23.88^{* *}$ \\
\hline & $(-4.62)$ & $(-4.68)$ & $(-4.47)$ & $(-4.47)$ \\
\hline Number of observations & 50 & 50 & 50 & 50 \\
\hline R-sared & 0.70 & 0.71 & 0.72 & 0.72 \\
\hline
\end{tabular}

Coefficients reported with t-values underneath. Robust standard errors

** and * represent 1 , and $5 \%$ levels of significance respectively

theory is indeterminate regarding the sign and significance. We report results estimated using OLS with robust standard errors in Table 4.

\section{Results and Discussion}

Table 4 presents the results of our analysis. The t-statistics are reported in parentheses under the coefficients. We find that migrant networks are an important determinant of undocumented migration in all four specifications - the presence of a large documented Hispanic population in a state has a positive and significant impact on undocumented migration at the $1 \%$ level. $^{5}$ Such clustering of undocumented migrants in states with large migrant networks is likely because the economic and non-economic costs associated with locating in such states and finding suitable employment are lower. ${ }^{6}$ Our results also support the importance of economic opportunities in an undocumented migrant's decision to locate in a state in all specifications. The coefficient of the median

\footnotetext{
${ }^{5}$ This can be interpreted as a $1 \%$ increase in the total Hispanic population in a state leading to a $0.36 \%$ increase in the percentage of illegal immigrants in a state.

${ }^{6}$ This finding, known as the "friends and neighbors effect," is to be expected (Cebula et al. 1973). 
real income in a state is positive and statistically significant at the $1 \%$ level. The state income tax dummy and the quality of life measures in a state, namely, the average January temperature, are both statistically insignificant in all specifications.

Our main variables of interest are the two educational access policy variables, ed_fav_im_dum (favorable ed. policy dummy) and ed_eff_yrs (number of years since favorable educational policy was enacted). In Table 4, Models 1 and 2, we find that the coefficients of both educational policy variables are negative and statistically insignificant. This is not a surprising result since previous studies have found limited impact of favorable educational access policies on college enrolment of undocumented students. This finding in the present study suggests that a similar impact is likely with respect to location decisions. In Models 3 and 4, we interact the educational access policy variables ed_fav_im_dum and ed_eff_yrs individually with the networks variable. This approach is motivated by the fact that the presence of a sizable network in a state can, as in the case of economic opportunities, lower the economic and non-economic costs associated with access to higher education and positively influence location choice. On the other hand, it may also result in greater competition for admission to higher education, and this may serve as a disincentive to undocumented migrants to take advantage of the favorable tuition opportunity. The sign of the interaction terms will depend on which effect dominates. If the positive cost reduction effect of networks dominates its negative competition effect, we expect the interactions terms in Models 3 and 4 to be positive and significant, or vice versa.

In Model 3, the coefficient on ed_fav_im_dum (favorable educational policy dummy) now changes signs and is positive and statistically significant as compared to Model 1, where its coefficient was negative and insignificant. The interaction term, ed_fav_networks is negative and statistically significant, indicating that the negative competition effect of networks is larger than the positive cost-reduction effect. The size of the network negatively moderates the impact of favorable educational access policies on location decisions and undocumented migrants appear to not to prefer residence in states with both large networks and favorable educational access policies. We use our alternate measure of educational access ed_eff_yrs (number of years since favorable educational access policy was enacted) and its interaction terms with our networks variable, ed_eff_networks, in Model 4 and find that the results in Model 3 are robust to the alternate proxy for the educational access policy variable. The policy became effective in New Mexico only in 2005, so as an additional robustness check we dropped New Mexico from the list of states with educational access policies favorable to undocumented migrants and re-estimated the regressions. The sign and significance of the educational access policy variables and their interaction terms with the network variable were similar to the results in Models 3 and 4. The other results also remained unchanged.

\section{Conclusions}

Many states have experienced a large influx of undocumented migrants in recent years. This research investigates whether favorable educational access policies at the state level influenced the location decisions of undocumented migrants in the U.S. in 2005. Our analysis suggests that there is likely to be clustering of undocumented migrants in 
states with large migrant networks, and good economic opportunities, as proxied by the state's median real family income. We have some exploratory evidence on whether educational access policies at the state level influence location choices of undocumented migrants. Our initial results suggest that while larger networks provide greater access to economic opportunities, they may also increase competition for admissions to higher education in states that have favorable educational access policies towards undocumented migrants. Hence, educational access policies for undocumented migrants are, ceteris paribus, less likely to act as a magnet for the influx of additional undocumented migrants.

Naturally, we consider these results to be exploratory. Thus, we present these results with several caveats. This analysis is limited by lack of direct measures of the number of undocumented migrants and the use of cross-sectional data for the year 2005 . Although the estimates of illegal migrants are calculated using rigorous methodology, they are nonetheless subject to a margin of error. Another reason for the limited impact may be the time frame of our study. The data on undocumented migrants is from 2005 while the first adoption of such educational access policies at the state level was in 2001 in Texas and California. Hence, there may not have been sufficient time to experience the full impact of these policies on location choices of undocumented workers. Moreover, there clearly may be several other factors that influence location decisions of undocumented migrants in the U.S., such as health care, intensity of deportation efforts at the state level, etc. that this study has not explicitly addressed. As better quality longitudinal data becomes more readily available, a dynamic analysis will be able to offer greater insights into the impact of educational access policies on the longer-run location choices of undocumented migrants.

\section{References}

Borjas, G. J. (1999). Immigration and welfare magnets. Journal of Labor Economics, 17(4), 607-637.

Bauer, T.K., Epstein, G.S., \& Gang, I.N. (2002). Herd effects or migration networks? The location choice of Mexican migrants in the U.S. IZA Discussion paper series, No. 551.

Biswas R.R. (2005). Access to community college for undocumented immigrants: A guide for state policymakers. http://www.williamperezphd.com/articles/biswas-2005.pdf.

Carrington, W. J., Detragiache, E., \& Vishwanath, T. (1996). Migration with endogenous moving costs. American Economic Review, 86(4), 909-930.

Cebula, R. J., \& Alexander, G. M. (2006). Determinants of net interstate migration, 2000-2004. Journal of Regional Analysis and Policy, 27(2), 116-123.

Cebula, R. J., Duquette, C. M., \& Mixon, F. G. (2013). Factors influencing the state-level settlement pattern of the undocumented migrant population in the U.S. Atlantic Economic Journal, 41, 203-213.

Cebula, R. J., Foley, M., \& Boylan, R. (2014). The impact of unionization and other factors on undocumented migrant settlement patterns in the U.S. Applied Economic Letters, 21(4), 272-275.

Chin A., and Juhn, C. (2010). Does reducing college costs improve educational outcomes for undocumented migrants? Evidence from state laws permitting undocumented migrants to pay in-state tuition at state college and universities, NBER Working Paper 15932, April 2010, (Cambridge, Mass.: National Bureau of Economic Research).

Conway, K. S., \& Houtenvile, A. J. (2003). Out with the old, In with the old: a closer look at younger versus older elderly migration. Social Science Quarterly, 84(2), 309-328.

Council of Economic Advisors. Economic Report of the President (February 2005). Washington: Government Printing Office. 
Dougherty, K. J., Nienhusser, H. K., \& Vega, B. E. (2010). Undocumented migrants and state higher education policy: the politics of in-state tuition eligibility in Texas and Arizona. The Review of Higher Education, 34(1), 123-173.

Dougherty, K., Nienhusser, H. K., \& Kerrigan, M. R. (2006). Helping students enter and succeed: access, success, and accountability policies in the "achieving the dream" States. Community College Journal, 77, 42-47.

Flores, S. M., \& Horn, C. L. (2009). College persistence and undocumented students at a selective public university: a quantitative case study analysis. Journal of College Student Retention, 11, 57-76.

Flores, S. M. (2010). State 'dream acts': the effect of in-state resident tuition policies on the college enrollment of undocumented Latino students in the U.S. Review of Higher Education, 33(2010), 239-83.

Gale, L. R., \& Heath, W. C. (2000). Elderly internal migration in the U.S. revisited. Public Finance Review, 28(2), 153-157.

Hausman C., and Goldman V. (2001). Great expectations. New York Times, April 8, 2001. http://www. nytimes.com/2001/04/08/education/great-expectations.html?pagewanted=5\&pagewanted=all.

Kaushal, N. (2008). In-state tuition for the undocumented: education effects on Mexican young adults. Journal of Policy Analysis and Management, 27(4), 771-792.

Nair-Reichert, U. (2014). Location decisions of undocumented migrants in the U.S. Journal of Regional Analysis and Policy, forthcoming.

National Conference of State Legislatures (2014). Allow in-state tuition for undocumented students. Retrieved July 1, 2014 from http://www.ncsl.org/research/education/undocumented-student-tuition-state-action. aspx.

Passel, J.S. (2005). Unauthorized migrants: Numbers and characteristics. http://www.pewhispanic.org/2005/ 06/14/unauthorized-migrants/.

Passel J.S. (2006). Size and characteristics of the unauthorized migrant population in the U.S. Pew Hispanic Center, Washington, DC. http://www.pewhispanic.org/2006/03/07/size-and-characteristics-of-theunauthorized-migrant-population-in-the-us/.

Passel, J.S. and Cohn D. (2011) Unauthorized immigrant population: National and state trends, 2010. Washington, DC: Pew Hispanic Center, Februrary. http://www.pewhispanic.org/files/reports/133.pdf.

Perry, A. (2004). Philosophical arguments of membership: The case of undocumented immigrants and financial aid for postsecondary education. Unpublished doctoral dissertation, University of Maryland, College Park.

Renas, S. M. (1983). The cost of living, labor market opportunities, and the migration decision: more on problems of misspecification and aggregation bias. Annals of Regional Science, 17(1), 98-110.

Riew, J. (1973). Migration and public policy. Journal of Regional Science, 12(2), 65-73.

Saltz, I. S. (1998). State income taxation and geographic labor force mobility in the U.S. Applied Economics Letters, 5(5), 599-604.

Szelenyi, K., \& Chang, J. (2002). ERIC review: educating immigrants: the community college role. Community College Review, 30(2), 55-73.

Tullock, G. (1971). Public expenditures as public goods. Journal of Political Economy, 79(5), 913-918.

U.S. Census Bureau (2005, 2006, 2007). Statistical Abstract of the U.S. Washington, D.C:U.S. Government Printing Office.

Vedder, R. K., Gallaway, L. E., Graves, P. E., \& Sexton, R. (1986). A historical perspective in interregional migration in the U.S. In R. J. Krumm (Ed.), Housing and migration (pp. 101-24). Mount Pleasant: Blackstone Books.

Zota S. (2008). Unauthorized immigrants' Access to higher education: Fifty States, different directions. Popular Government, Spring/Summer, 46-54. 